\title{
Lithuanian Literature and Shakespeare: Several Cases of Reception
}

\author{
EGLE் KETURAKIENE்
}

\begin{abstract}
The article is based on the reception theory by Hans Robert Jauss and analyses how Shakespeare's works were read, evaluated and interpreted in Lithuanian literature in the $19^{\text {th }}$ to $21^{\text {th }}$ centuries. Some traces of Shakespeare's works might be observed in letters by Povilas Višinskis and Zemaite where Shakespearean drama is indicated as a canon of writing to be followed. It is interesting to note that Lithuanian exodus drama by Kostas Ostrauskas is based on the correspondence between Višinskis and Zemaite. The characters of the play introduce the principles of the drama of the absurd. Gell's concept of distributed personhood offered by S. Greenblatt is very suitable for analysing modern Lithuanian literature that seeks a creative relationship with Shakespeare's works. The concept maintains that characters of particular dramas can break loose from the defined interpretative framework.

Lithuanian exodus drama reinterprets Shakespeare's works and characters. The plays by Ostrauskas and Algirdas Landsbergis explore the variety of human existence and language, the absurd character of the artist, meaningless human existence and the critique of totalitarianism. Modern Lithuanian poetry interprets Shakespeare's works so that they serve as a way to contemplate the theme of modern writing, meaningless human existence, the tragic destiny of an individual and Lithuania, miserable human nature, the playful nature of literature, the clownish mask of the poet, the existential silence of childhood, the topic of life as a theatrical performance, the everyday experience of modern women in theatre. The most frequently interpreted dramas are Hamlet, King Lear and Macbeth - Lithuanian literary imagination inscribed them into the field of existentialist and absurd literature.
\end{abstract}

Keywords: Shakespeare; reception theory; Lithuanian literature; distributed personhood; existentialist philosophy; absurd drama

There are not many literary texts about the links between the oeuvre of William Shakespeare and Lithuanian literature. One could mention Delija Valiukenaitë's work (Valiukenaite 1972) about the Lithuanian translations of Shakespeare. Aušra Jurgutienè has written one of the most interesting deconstructive analyses of Shakespeare's King Lear showing it to be "full of 
paradoxes and contradictions" (2003: 42) and that it might be suitable for a deconstructive reading. Jolanta Kriūnienè has written about the links between Shakespeare's works and the poetry of Vytautas Mačernis (Kriūnienè 2002). Reda Pabarčiene has discussed "the influence of Shakespearen drama on Lithuanian historical drama, [...] on the works of M. Šikšnys, V. Krèvė, B. Sruoga, J. Grušas" (Pabarčienè 2006: 110). Silvestras Gaižiūnas has focused on the connection between Shakespeare's Hamlet and the play Tyru vienuolis (The Coenobite of Chastity) of Albinas Herbačiauskas (Gaižiūnas 2009). Justina Juozapavičiūtës Master's thesis was based on the formalistic analysis of the structure of modern Lithuanian drama (Juozapavičiūte 2011).

This article will address the question of how Shakespeare's works were perceived, read and evaluated by the Lithuanian reader in the $19^{\text {th }}$ and $20^{\text {th }}$ centuries, what other meanings did Shakespeare's texts acquire. Reception theory by Hans Robert Jauss puts the reader in the role of a co-author, a creator who revives a piece of art from the past and gives it a new life. Jauss points out that "only through the process of its mediation that the work enters into the changing horizon - of - experience of a continuity in which the perpetual inversion occurs $[\ldots]$ from passive to active reception, from recognized aesthetic norms to a new production that surpasses them" (2005: 19).

Translations of Shakespeare's works reached the Lithuanian reader only at the end of $19^{\text {th }}$ century. According to the expert of Shakespeare, Delija Valiukenaite, Jurgis Sauerwein's translation was the only one available in Lithuania in the $19^{\text {th }}$ century. However, the audience in the $18^{\text {th }}$-century Lithuanian-Polish Republic was acquainted with Shakespeare's plays: "Hamlet's monologues, translated by Sauerwein, were published in the newspaper "Auszra" and Lithuanian calendar "Auszra" [...], however, the plays were first performed [in Lithuania] almost in Shakespeare's epoch. Green from England visited Lithuanian-Polish Republic on tour in 1634 where Shakespeare's plays, patronized by Wladislaw IV, were performed in one of the yards of Vilnius castle" (Valiukenaite 1972: 19). Traces of Shakespeare's reception can be observed in the literary criticism of the Lithuanian classical poet Maironis (1862-1932). According to Maironis, "English drama reached its highest peak in the works by Shakespeare [...]" (1992: 332). As one of the main values of Shakespeare's dramas Maironis mentions realism typical of his works, convincing psychological characters, as well as resistance of Shakespeare's works to time and thus their eternal relevance because Shakespeare is understandable to readers of all nations and all times. Povilas Višinskis (18751906), a Lithuanian educator, activist of culture and writer who lived at the end of the $19^{\text {th }}$ and the beginning of the $20^{\text {th }}$ century, spoke about Shakespeare's 
works in his letters to Žemaite (1845-1921). The Renaissance author is treated as a great authority. Višinskis encourages the use of principles of classical drama employed by Shakespeare (1964: 334). In his letters to Žemaitė, Višinskis invites the reader to discover how Shakespeare depicts human feelings, how the most important thing in Shakespeare's works is the human being, that the names of the main characters also serve as titles of the plays (ibid. 325). In his letter written in Yalta on 19 May 1898, Višinskis expresses great joy over Žemaitë's story Petras Kurmelis where, in his opinion, Shakespeare's influence has made the descriptions of the landscape dynamic, not boring (ibid. 341). Žemaite, a Lithuanian writer of realistic prose in the $19^{\text {th }}$ century, admits in her replies to Višinskis that she finds Shakespeare's works the most understandable in world literature. In a letter dated $5^{\text {th }}$ May 1889, in Ušnènai, she writes that she admires Shakespeare's ability to depict the passion of love as inseparable form a human being, especially a young one (Žemaitè 1957: 78).

\section{Lithuanian Exodus Literature and Shakespeare}

The Lithuanian dramatist Kostas Ostrauskas's (1926-2012) play Žemaité sutinka Šekspyra (Žemaitè Meets Shakespeare, 2006) is based on Višinkis and Žemaitè discussing Shakespeare's works in their letters. According to Loreta Mačianskaite, Ostrauskas is a "Lithuanian Beckett, the first absurd dramatist, the first postmodernist. These epithets were applied to Kostas Ostrauskas and they are likely to multiply in the future and yet none of them grasp the real value of his works and impact on Lithuanian culture" (2014: 7). Furthermore, the author himself remained indifferent to such definitions which is understandable as it is impossible to frame creative works according to certain interpretations designed in advance, even though the listed epithets partially point to the specificity of Ostrauskas's works.

It is possible to find many quotations from Shakespeare's works in Ostrauskas's play. They are mainly indicated by the quotation marks, hence easily recognizable, however, Shakespearean characters and Shakespeare himself as a character play a much more important role. Thus, the concept of a "distributed personhood" formulated by the English anthropologist Alfred Gell and described by Stephen Greenblatt is quite applicable to Ostrauskas's plays. It points to the artist's ability to model a shape which becomes a character in its own right, the artist's or another character's world that can affect others or can be affected himself. Gell calls it "index" (Greenblatt 2016: 5). According to Greenblatt, "a part of an artist's personality separates from the body and remains even after the artist himself stops existing physically. These 
"distributed" parts of an artist's personality are transformed and continue existing by becoming a source for new experiences" (2016: 5). Shakespeare as a character and Shakespeare's characters obey the postmodern imaginary metamorphosis of an artist in Ostrauskas's plays. In Greenblatt's words, "they step out from particular narrative structures with prescribed roles" (ibid.). It is possible to say that Ostrauskas as an active reader gets involved in the infinite world of interpretation and by making relevant both world literature and Lithuanian classical literature, enlivens them. For instance, in a short play Ofelija, Hamletas ir ... Veronika? (Ophelia, Hamlet and ... Veronica?, 2009), he revives the two literary women who drowned - Ophelia and the Lithuanian Veronica from Antanas Vienuolis's story Paskenduole (The Drowned). The creation of a new language is the most important thing for Ostrauskas. Characters of his play become rather rational in the new literary environment, Ophelia even quotes Hamlet's words that one must doubt everything, including literary reality, its beautiful "words, words, words". Aušra Martišiūte highlights that "paradox is [...] a peculiar feature of intertextuality in his plays" (2007, s.p.). Futhermore, Ostrauskas, like Shakespeare, likes ambiguity. This feature is familiar to Žemaitës realistic writing.

In Ostrauskas's play Žemaitè sutinka Šekspyra (Žemaitè Meets Shakespeare, 2006), the two characters - dramatists Žemaite and Shakespeare - discuss the principles of drama while the characters themselves represent not only different cultural epochs (Renaissance and Lithuanian realism) but different speech modes of drama: the figure of Shakespeare stands for a polite literary speech, whereas Žemaite is abrupt and harsh (Ostrauskas 2014: 191). The dialogue of the two characters in Ostrauskas's play is mainly based on opposition that is close to the stylistics of absurd drama when two characters fail to communicate effectively and do not understand one another. The artist makes it clear that Shakespeare often talks to the public, not to Žemaitè. In one episode of the play, Shakespeare starts putting the words of Hamlet into English, while Žemaite cannot grasp the meaning of all this and starts begging for help. The principle of opposing the speeches of the characters employed by Ostrauskas in order to deny or "erase" the attitude of an opponent is very close to the speech modes in Beckett's plays. According to Martin Esslin, "in fact the dialogue in Beckett's plays is often built on the principle that each line obliterates what was said in the previous line. [...]" (1968: 43) Nevertheless, it has to be mentioned that Ostrauskas's play is neither a pure absurd drama nor an imitation of Beckett's style. The play rather explores what Shakespeare and Žemaite have in common, why this meeting in the text is possible despite the enormous distance in space and time. Namely, it is the human world that dominates the works of both 
Shakespeare and Žemaitè. The world of man and the theme of creation depicted in Ostrauskas's play correspond to the context of existentialism. Albert Camus in his Conquest wrote: "the creature is my native land. This is why I have chosen this absurd and ineffectual effort” (1991: 87).

The figure of Shakespeare represents the alter ego of Ostrauskas himself in the play. He denies the need for comments. Epilogue of the play serves as an explanation; it is an unnecessary addition to the work. The idea is vividly illustrated at the end of the play when Žemaite talks to her husband Žymantas who fulfills the function of an unnecessary epilogue in the play. The light of clarity was essential to existentialism (Camus), whereas absurd drama lost faith in the possibility of explaining or revealing anything. Ostrauskas expresses the same opinion as Camus in Absurd Creation: "For the absurd man it is not a matter of explaining and solving, but of experiencing and describing" (1991: 94).

The anthropological idea of a "distributed personhood" is developed in other plays by Ostrauskas. For instance, in the short play Ir Žemaitè, ir Šekspyras, ir Šekspyras, ir Žemaitė (And Žemaitè, and Shakespeare, and Shakespeare, and Žemaitè), Ostrauskas seeks to reveal the connection between the two: the fact that they both lack university education which still did not stop them from becoming writers. However, Ostrauskas is not a consistent supporter of postmodern relativism because both Shakespeare's and Žemaitë's voices establish the undeniable difference between the two.

The Lithuanian dramatist criticised Roland Barthes's idea of "the death of the author”. Ostrauskas's play Trys laiškai i Parnasa (Three Letters to Parnassus) from his collection Paskutinis kvartetas (The Last Quartet, 2014) addresses Mozart, Shakespeare and Bosch - his artistic authorities. The letter to Shakespeare not only reveals his knowledge of Shakespeare but also the imperfection and poly-significance of the human nature typical of Shakespeare's characters.

The background of another play by Ostrauskas, Stratfordo sodininkas (The Stratford Gardener) from Užgavenių kaukès (The Carnival of Masks, 2006) is the life story of the artist which is presented as a conversation of Shakespeare with Ben Jonson and Dryden about life, writing, love. Shakespeare is depicted as having already abandoned writing for good and dedicating himself to working in his garden. Semantic threads of physical and spiritual weariness, his ghostly past life, exhaustion, love, meaning of creating, survival and nonmeaning, self-definition, eternity which is ignorant of history and tends to fade away are scattered throughout the textural cloth of the play. 
Ostrauskas mainly cares about the everyday existence of man, he turns the greatest writers into common people and shows them as sinful. Thus, on the one hand, the play Stratfordo sodininkas is close to existentialism, especially considering Sartre's idea that "essence precedes existence" (Sartre 2007: 20). On the other hand, the play comes close to "zero-degree writing" typical of absurd drama, to the description of uselessness of life and writing. The figure of the writer, Shakespeare himself, embodies doubts of Hamlet, "the zero" existence of King Lear ("I am very foolish, fond old man, / Fourscore and upward" (Shakespeare 2005: 239)), and Macbeth who has lost the aim and meaning of life. The end of Stratfordo sodininkas indicates the shift from "what if" to the question of authorship, whether writing depends on circumstances. Thus, Ostrauskas, just as Camus, presents the idea of the uselessness of a man's life and writing, about "the most absurd character - the creator" whose whole magnificence lies in his refusal to entertain any illusions.

The so-called Lithuanian neo-romantics were also familiar with Shakespeare's works. This can be observed in Jonas Aistis's (1904-1973) memoirs and modern poetry. In his memoirs Apie laika ir žmones (On Time and People, 1954), in the chapter Knygos - mielosios drauges (Books - Kind Friends), Aistis writes that Shakespeare was the first author who "enslaved" him in the first grade of the gymnasium (1993: 296). He says that he attempted to translate King John and Romeo and Juliet but the enthusiasm of the young poet was extinguished by a specialist who read his manuscript and told him that "the translator lacks knowledge of composing lyrics" (ibid.).

This literary "friendship" and context of Shakespeare's works left traces in Aistis's poetry. In his poem Karalius Lyras (King Lear), the imagination of the poet compares the misery of autumn to King Lear's banishment from home (Aistis 1988: 45). The poem makes it clear that autumn misery belongs to literary reality - the autumn misery experienced by the character of the poem is turned into a scene from Shakespeare's drama. The poem creates a lyrical image of King Lear (there is a pun in Lithuanian as the word "lyrical" has similar semantics as "Lear") which is the opposite of the rough personality described by Shakespeare. In Aistis's poem, the madness of Lear is shown as naïve; it is a poetic speech not on Shakespeare's drama but rather a criticism of the naïve romantic approach to life. In another poem Ofelija (Ophelia), an interesting transformation of Hamlet's beloved can be observed: she becomes a holy nymph of the poet who is begged to mention the sinful speaker in her prayers. In the poem Kaip Šekspyro tragedijoje (Like in Shakespeare's Tragedy), the image of a bloody and sweaty evening reminding that of Christ's Passion is compared to scenes from Shakespeare's tragedy. However, the text is overcome 
by nature: the light of firmament does not need "sickly words", hence, the poem speaks about feebleness of writing, that there is more suffering in nature than in literature (Aistis 1988: 67).

Signs of the reception of Shakespeare's works might be found in the intellectual exile poetry by Alfonsas Nyka-Niliūnas (1919-2015). The poet of Lithuanian modernism translated Shakespeare's Hamlet and wrote an article on it titled Hamletas (Hamlet). According to Nyka-Niliūnas, "Hamlet is neither a weak nor milk-and-water man only his actions were lacking in barbarian passion, [...] his death is [...] the event of absurd being" (1996a: 435). The whole poetry by Nyka-Niliūnas is based on Hamlet's question "to be or not to be" which absorbed existentialism and absurd literature. A philosophical poem Macbeth (Macbeth) by Nyka-Niliūnas (from the collection Vyno stebuklas (Miracle of Wine), written in Baltimore in 1957) masterfully develops the topic of the meaninglessness of life typical of existentialism, and later of absurd literature; the topic is related to Macbeth's words in Shakespeare's tragedy pronounced after the death of his wife: "tomorrow, and tomorrow, and tomorrow" (Shakespeare 2005: 97). According to Dovydas Judelevičius, the monologue of Macbeth expresses "the last limit of disappointment" (1964: 155).

An eloquent scene of knocking on the gates recurring in Shakespeare's Macbeth is interpreted in a new way in Nyka-Niliūnas's poem Macbeth. Other Lithuanian authors also like this Shakespearean motif of knocking on the gates, for instance, Ostrauskas in his play Who's There? The Shakespearean metaphor of knocking on the gates representing fear is transformed in NykaNiliūnas's poem into a repetitive knocking of another day which signifies the awful monotony of a human life, meaningless emptiness (1996b: 248). The subject of his poem is Macbeth of the new age who attempts to kill himself and not Duncan, the king of Scotland. The metaphor of existence, an unborn child, refers to the inability of the character to find the way of meaningful existence, hence his inability to find his authentic existence, to be himself. The life for Nyka-Niliūnas's character is only the experience of total meaninglessness expressed as the endless travelling of a man from one circle to another (an allusion to re-designed circles of Dante's Inferno; the image of the world as hell also occurs in Act III of Hamlet) which leads to suicide. The motif of the meaninglessness of life in the poem is expressed by Macbeth who comes up with such metaphors as life as a running shadow, life as a comedian, life as a tale of an idiot.

These metaphors appear in plays by Algirdas Landsbergis (1924-2004). Postmodern plays Komediantai (Comedians) and Idioto pasaka (The Tale of 
an Idiot) by Landsbergis depict human life as that of a clown, that is, stable and immutable existence is questionable. Landsbergis's play Komediantai criticizes totalitarian society which forbids laughing, theatre, criticism. Laughter is a human peculiarity according to Landsbergis and one can see the unearthly smile of Buddha's spirit in the skies (1994: 73). Criticism of totalitarianism merges with the principles of modern drama. In the play, identities of characters from Shakespeare's plays are de-constructively mixed, characters from Hamlet and The Tempest are brought to new life, the author plays with the significances of Shakespeare's plays, only the figure of Shakespeare himself embodies the very canon of literature, a fatherly celestial voice of truth.

\section{Lithuanian Modern Poetry of the $20^{\text {th }}$ and the $21^{\text {st }}$ century and Shakespeare}

Shakespeare's works and personality play an important role in modern existential poetry by Tomas Venclova (1937). In the poem Klaipedos kanalas. Piešinys (Canal of Klaipeda. A Drawing), Venclova gives a phenomenological description of the scenery and lists the predecessors of his works - poets of great authority - Shakespeare, Block and Rimbaud (1991: 61). Venclova has translated Shakespeare's The Tempest and chosen Hamlet as an intertext for his own works. The heading of the poem Pasakykite Fortinbrasui (Tell Fortinbras) from the collection Kalbos ženklas (The Sign of Language, 1972), is the voice of dying Hamlet from Act V, Scene II where Hamlet addresses his friend Horatio to prophesy the victory for Fortinbras. A researcher of Tomas Venclova's works, Donata Mitaite, states that "in the opinion of readers and critics, this poem is very important among the works of Venclova as it reveals the essence of life in a totalitarian world" (2002: 70). The poem is the warning of the poet-dyingHamlet against "their" - subjugated nations' - refusal to resist, rebel and falling into historic and political slavery.

The intertext from Shakespeare's Hamlet is found in Janina Degutytës (1928-1990) poetry which embodies Lithuanian cultural memory. Her poetry shows a strong inclination to folklore and mythology, there are clear archetypes of the world tree, sun, water, earth (Daujotyte 1988: 11), however, at the same time the poetess contemplates on the memory of world literature and culture. She associates the figures of Antigone, Judas, Don Quixote, Scheherazade, Odyssey, Thyl Ulenspiegel and Hamlet with the tragic destiny of man and the tragic history of Lithuania in the cycle of poems Roles (Roles). The question "to be or not to be" is repeated as a dominating metaphor in her poem Hamletas (Hamlet); it serves as a historical question of survival that finally leads to the 
conclusion that admiration of nature is the only choice for a human, thus she can be classed as an existentialist.

The title of Aidas Marčènas's (1960) book of poetry - Vargšas Jorikas (Poor Yorick, 1998) - hints at its playful nature. The poem also titled "Poor Yorick", from the collection Eiline (Ordinal, 2006), presents one of the favourite themes of the poet, it is integrated into the poetic situations of Shakespeare's drama Hamlet. In Act V, Scene I, when the grave diggers dig out the scull and one of them recognized a dead clown, Hamlet holds the scull in his hand and shouts: "Alas, poor Yorick! I knew him, Horatio: a fellow/ of infinite jest, of most excellent fancy: he hath/ borne me on his back a thousand times; and now, how/ abhorred in my imagination it is! my gorge rims at/ it." (Shakespeare 2003: 231-232) While in Shakespeare's tragedy Hamlet's speech refers to overpowering death ("Where be your gibes now? Your/ gambols? your songs? your flashes of merriment,/ that were wont to set the table on a roar? Not one/ now, to mock your own grinning?” (ibid.), in Marčenas's poem the poet identifies himself with the fate of Yorick. Hamlet treats himself as a clown in Shakespeare's drama. In Act III, Scene II, Hamlet ironically tells Ophelia he is her only clown and a human would have nothing else to do besides making merriment. Thus, the poet-clown mask in Marčènas's poem hides an ironical attitude to life and creator. Marčènas shows the Prince of Denmark taking the scull of the poet in his hands and being sorry that both head and poetry are dominated by emptiness and boredom (2006: 242). The reference to inescapable death so clear in Shakespeare's Hamlet is changed in Marčènas's poem into that of learning poetry, the lines that resemble a nursery rhyme (ibid.). Also in the poem by Sigitas Parulskis (1965) Poetiniai interesai (Poetical Interests) the whispering of the ghost of Hamlet's father to his son expresses the relationship between reality and poetry (2018: 187). In postmodern playful poetry by Gintaras Patackas (1951), in the poem Pagal Shakespeare (According to Shakespeare) Shakespeare's works become an existential meta-code (2011: 90).

\section{Lithuanian Contemporary Women Poetry and Shakespeare}

Danute Paulauskaitè (1945-2004), a Lithuanian poetess of peculiar style, loved Shakespeare's works as well. Her language is ascetic, moderate, leaving much space for the reader. The speaker of the poem Eidama paskui (Going After) feels betrayed by the strangeness of the world and thus domesticates literature, that uninterested art that "mocked useless beauty of the world" (Paulauskaite 2001: 69). The poetical subject does not deny the existence of the world because one 
cannot isolate oneself from it. Yet it is impossible to survive without poetry. It is the only comfort and shelter from loneliness and sorrow that serves as a link to life, therefore Hamlet's Ophelia in the poem Eidama paskui turns into the sister of the lyrical subject Ophelia who has come from the land of childhood, who is drowning but never drowns (2001: 69). In the poem In the Shakespeare Class, Shakespeare and his Hamlet serve as metaphors for past school time as well as an expression of the truth of existence that has turned into Hamlet-like silence opposed to the lies and deceit of the world (2002: 108). The existentialist image of man becoming human is found in the poem while the most important things are not told and revealed. To put it in Camus's words, "a man is more a man through the things he keeps to himself than through those he says" (1991: 84-85).

Tautvyda Marcinkevičiutè (1955), another Lithuanian poetess of modern poetry, has translated a cycle of Shakespeare's sonnets into Lithuanian. An endeavour to name the everyday experience, especially that of a woman, and an attempt to make it a surrealistic image is typical of Marcinkevičiutës postmodern poetry. Just as the postmodern drama of Ostrauskas, the intertextual poetry by Marcinkevičiutė presents the transformed "distributed personhood" of Shakespeare. Surrealistic figures of dark-faced Shakespeare or bearded Shakespeare appear in Marcinkevičiutës poems. For instance, the poem Tamsiaveidżiui (To the Darkfaced), from the collection Juodasis asfalto veidrodis (Black Mirror of Asphalt, 1998) is modelled as a conversation addressing Shakespeare himself. The title of the poem is a peculiar game with the reader who must remember that in Shakespeare's sonnets love is dedicated to a dark lady, whereas in Marcinkevičiutè's text it is transformed into a dark-faced beloved of Shakespeare that remains a secret to the lyrical subject. A sonnet is written to him in a dream. Dreamt Shakespeare is compared with a secret spark of baptism, with life typical of children, inscribed into the experience of womanhood of the lyrical subject (Marcinkevičiute 1998: 11). One may go back to the Renaissance in a dream but the lyrical subject does not take the love of Ophelia (insane) for the expression of real love (ibid.). In Marcinkevičiūtès poem 23 April 1564, Shakespeare, the personal topic of writing intermingles with the experience of womanhood, giving birth and a phantasmagorical vision where details of Shakespeare's life get mixed with an erotized surrealistic phantasy (Marcinkevičiute 1998: 9). In another poem she plays with the rumour that his name was misspelled in his last will. The poetess makes a very subtle opposition to this image of apparently illiterate Shakespeare by putting two characters - Shakespeare and Dostoyevsky - into one feast in eternity (Marcinkevičiūtė 1998: 10). 
The tenth book of poetry by Dovile Zelčiūte (1959) titled Džuljetos suknelè (The Dress of Juliet, 2013) is made of poetic variations on Shakespeare's Romeo and Juliet, Hamlet, The Tempest and Othello. They are inscribed into the contemporary woman's experience of theatre and everyday life. The theme of life-theatre is obvious in Shakespeare's Hamlet, the topic is also discussed by Camus in Drama based on the interpretation of Shakespeare's Hamlet. Her book uses Shakespearean and existentialist metaphors of performance-life, when a performance turns into life and life into performance, when the lyrical speaker of the poem is both an actress playing Ophelia and a spectator of the play (Zelčiutè 2013: 7). The situation of the theatre within theatre is inscribed into the scene of postmodern poetry. It is inseparable from the autobiographical text of the poetess (both of her parents were actors, so she spent nearly all her childhood in the theatre). The speaker of the poem O Hamletas sake (But Hamlet Said) desires that Hamlet being played should become a counterbalance to the noise of the information society, a silent resistance to contemporary everhurrying consumer society (ibid.).

The subject of Zelčiūtè poetry, to use Camus's words, takes over the lives of Ophelia, Juliet, Miranda and "carries them with him that they somewhat overflow the time and place in which they were born. They accompany the actor, who cannot very readily separate himself from what he has been" (1991: 79). The subject does not play the characters of Shakespeare's dramas, she is merely the new-age Miranda, Ophelia, Juliet. The poems Ofelija. Monologas I, II, II (Ophelia. Monologue I, II, III), speak about the destiny of Shakespeare's Ophelia as an experience of the modern woman. The poems as well as the whole book are dedicated to fragile love relationships in the past.

The speaker of Zelčiūtë's poetry is a wanderer through time and space as well as souls of characters. In Camus's words, "by sweeping over centuries and minds, by miming man as he can be and he is, the actor has much in common with that other absurd individual, the traveller" (1991: 79). For Camus, absurd actor is "a traveller in time and, for the best, the hunted traveller, pursued by souls” (ibid.). The poem Džuljeta Krajovoj (Juliet in Craiova) as well as the title of Zelčiūtès book Džuljetos suknelè embodies the archetypal metaphor of performance-life. In Sartre's words, "it is almost impossible to distinguish between playacting and true feelings” (2007: 32). The poem Džuljetos žalioji (Juliet the Green) speaks about the existential free choice of a woman that is in contrast to the order in theatre. In Sartre's words, "if we define man's situation as one of free choice, in which he has no recourse to excuses or outside aid" (2007: 47). The speaker of Zelčiūtè poetry is careful about the existence of a thing: the dress not only embodies the nature of the woman-actress, but it 
may also be conceived of as a metaphor of existentialist art because drama, in Camus's opinion, is when one can maximally enter the lives of others: "for that is his art - to simulate absolutely, to project himself as deeply as possible into lives that are not his own" (1991: 79). To choose a dress in the poem means a moment of freedom to choose one's destiny. The dress serves as a metaphor of life and death.

\section{Conclusion}

Letters by Višinskis and Žemaite at the end of the $19^{\text {th }}$ and the beginning of the $20^{\text {th }}$ centuries established the significance of Shakespeare's drama as one of the fundamental canonical text of western literature for the Lithuanian reader. Ostrauskas's dramas reveal that the works of the playwright balance between existentialism and the absurd. The difference of individuality accentuated in existentialism is manifested by the varying language of characters in his plays. Moreover, postmodern playfulness is typical of his plays: here Shakespeare acquires the features of his own characters (Hamlet, King Lear, Macbeth) which manifest aesthetics of the absurd. In the play, the character called Shakespeare stands for the Lithuanian author who refuses to explain his work and points to the most absurd human, the writer as an ordinary human being. In postmodern plays by Landsbergis, Shakespeare becomes a symbolical figure of non-achievable truth, while the poetics of Shakespeare's dramas turn out to be the foundation of the postmodern interpretation which merges the topics of writing and criticism of totalitarianism. Aistis uses Shakespeare's works as an intertext to criticise romantic naivety and to highlight the distinction between nature and human artistry, artistry. Nyka-Niliūnas emphasizes a Macbeth-like attitude of the poet accentuating the sinfulness of the poet, the meaninglessness of life and lack of hope typical of both existentialism and the absurd. In the poetry of Venclova, intertext of Shakespeare's drama serves as a warning to protect freedom, as well as an existential sign of the emptiness of life. Patackas uses Shakespeare's works in his postmodern poetry as a metacode that allows him to openly tell the truth about the painful past and present of Lithuania, while in the poetry of Marčenas, the mask of the jester opens up a possibility to talk about the nature of playful art works as well as the purpose of the poet. In the poetry of Parulskis intertext from Hamlet expresses the theme of creation and reality.

The relationship between modern poetry by women and Shakespeare is manifold, ranging from the existential contemplation of Lithuania and the destiny of an individual (Degutytè), the surrealist vision (Marcinkevičiūtè), 
silent existence (Paulauskaite) to the existentialist metaphor of life as theatre (Zelčiūtè).

Thus, it is possible to come to the conclusion that Shakespeare's works have been one of the most important sources that nourished modern and postmodern Lithuanian literature.

\author{
Eglè Keturakienè \\ egle.keturakiene@knf.vu.lt,egle_klimaite@yahoo.com \\ Vilnius University \\ Kaunas Faculty \\ Muitinè g. 8 \\ LT - 44280 Kaunas \\ LIETUVA / LITHUANIA
}

\title{
Bibliography
}

Aistis, J. 1988. Raštai. T. I. Chicago: Ateities literatūros fondas.

Aistis, J. 1993. Apie laiką ir žmones. - J. Aistis, Raštai, T. II.

Camus, A.1991. The Myth of Sisyphus and Other Essays. Trans. from the French by J. O'Brien. New York: Vintage Books.

Daujotytė, V. 1988. Ant ribos ir begalybeje. - J. Degutytė, Rinktiniai raštai T. 1. Vilnius: Vaga, 5-22.

Degutytè, J. 1988. Rinktiniai raštai T. 1. Vilnius: Vaga.

Esslin, M. 1968. Samuel Beckett. - M. Esslin, The Tradition of the Absurd. Harmondsworth: Penguin Books, 29-87.

Gaižiūnas, S. 2009. Hamleto ir Shakespeare'o vieta ars amoris istorijoje. - S. Gaižiūnas, Klajojantys siužetai baltų literatūrose. Vilnius: LLTI, 207-219.

Greenblatt, S. 2016. Kaip Šekspyras gyvuoja dabar. - Šiaurès Atėnai 8, April 15, 5. Transl. by A. Patiomkinas.

Jauss, H. R. 2005. Toward an Aesthetic of Reception (Theory and History of Literature, vol. 2). Trans. by T. Bathi. Minneapolis: University of Minnesota Press.

Judelevičius, D. 1964. Gyvasis Šekspyras. Vilnius: Vaga.

Juozapavičiūtè, J. 2011. W. Shakespeare'o intertekstai šiuolaikineje lietuvių dramaturgijoje (A. Landsbergio, K. Ostrausko, T. Šinkariuko pjeses). Kaunas: VDU, http://vddb. laba.lt/ [master thesis].

Jurgutienè, A. 2003. Dekonstrukcija. Vilnius: VPU.

Kriūnienė, J. 2002. Vytautas Mačernis ir Vakarų kultūros kontekstai. Kaunas: VDU.

Landsbergis A., 1994. Du utopiški vaidinimai: Komediantai. Idioto pasaka. Chicago: Algimanto Mackaus Knygų Leidimo fondas.

Mačianskaitė, L. 2014. Sub specie vitae. - K. Ostrauskas, Paskutinis kvartetas. Vilnius: LLTI, 7-14. 
Lithuanian Literature and Shakespeare: Several Cases of Reception

Maironis, 1992. Anglų literatūra. - Maironis, Raštai T. III. Vilnius: Vaga, 322-354.

Marčènas, A. 2006. Eilinè: rinktiniai eileraščiai. Vilnius: Lietuvos rašytojų sąjungos leidykla.

Marcinkevičiūtè, T. 1998. Juodasis asfalto veidrodis. Vilnius: Lietuvos rašytojų sąjungos leidykla.

Martišiūtė, A. 2007. Paradokso poetika Kosto Ostrausko dramose. - http://www. tekstai.lt/tekstai-apie-tekstus/6407-ausra-martisiute-paradokso-poetika-kostoostrausko-dramose (13.11.2019).

Mitaitè, D. 2002. Tomas Venclova: biografijos ir kūrybos ženklai. Vilnius: LLTI.

Nyka - Niliūnas, A. 1996a. Temos ir variacijos: literatūra, kritika, polemika. Vilnius: Baltos lankos.

Nyka - Niliūnas, A. 1996b. Eilèraščiai (1937-1996). Vilnius: Baltos lankos.

Ostrauskas, K. 2006. Stratfordo sodininkas. - K. Ostrauskas, Užgavėniu kaukès: dramos ir teatras. Vilnius: LRSL, 135-154.

Ostrauskas, K. 2014. Paskutinis kvartetas. Ed. by L. Mačianskaitė. Vilnius: LLTI.

Pabarčienè, R. 2006. Lietuvių istorinès dramos dialogas su Williamo Shakespeare'o tradicija. - Acta litteraria comparative. Vilnius: VPU, 110-118.

Parulskis, S. 2018. Subjektyvi kronika. Ed. by D. Satkauskytė. Vilnius: LLTI.

Patackas, G. 2011. Manęs nebebus kai kada. Kaunas: Kauko laiptai.

Paulauskaitè, D. 2001. Dviese su namais: eilerraščiai. Vilnius: Vaga.

Paulauskaite, D. 2002. In the Shakespeare Class. Five Lithuanian women poets. Selected and translated from the Lithuanian by J. Zdanys. Vilnius: Vaga.

Sartre, J.-P. 2007. Existentialism is a humanism. Trans. by C. Macomber. New Haven and London: Yale University.

Shakespeare, W. 2003. Hamlet, Prince of Denmark. Ed. by P. Edwards. Cambridge: Cambridge University Press.

Shakespeare, W. 2005. The tragedy of King Lear. Ed. by J. L. Halsio. Cambridge: Cambridge University Press.

Shakespeare, W. 2005. Macbeth. Ed. by C. Watts. Ware: Wordsworth Editions.

Valiukènaitè, D. 1972. Šekspyras lietuviškuose vertimuose ir jų panaudojimas Šekspyro analizei. - Metmenys, 23, 18-39.

Venclova, T. 1991. Pašnekesys žiemą: eileraščiai ir vertimai. Vilnius: Vaga.

Višinskis, P. 1964. Raštai. Vilnius: Vaga.

Zelčiūtè, D. 2013. Džuljetos suknelè. Vilnius: Lietuvos rašytojų sąjungos leidykla.

Žemaitè, 1957. Raštai 6: laiškai. Vilnius: Valstybinè grožinès literatūros leidykla. 